\title{
Clinical usefulness of serial neutrophil geletinase- associated lipocalin (NGAL) change as a predictor for acute kidney injury
}

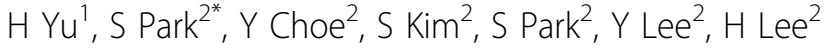 \\ From ESICM LIVES 2015 \\ Berlin, Germany. 3-7 October 2015
}

\section{Intr}

Plasma neutrophil geletinase-associated lipocalin (NGAL) has been regarded as one of the valuable markers of development of acute kidney injury (AKI) in ICU admitted patients. However, clinical significance of short-term change of plasma NGAL was not clearly investigated.

\section{Methods}

50 patients who admitted intensive care unit (ICU) was included by prospective manner. We analyzed plasma NGAL level by Triage immunoassay on ICU admitted time and 12 hours after. Change of estimated glomerular filtration rate (by MDRD equation) and need of renal replacement therapy was investigated. Patients with chronic kidney disease were excluded.

\section{Results}

Persistent elevation of plasma NGAL above $1000 \mathrm{ng} / \mathrm{mL}$ on 0 and 12 hours was significantly associated with need for early renal replacement therapy. Patient with increased level of NGAL at 12 hours showed unfavorable outcome which is related to renal replacement therapy or progressive renal impairment $(13 / 25 ; 48 \%$ of patients). Conversely, 2/17 (11.8\%) of patients had poor renal outcome when NGAL decrease more than $20 \%$ from baseline at 12 hours after ICU admission. On multivariate analysis, baseline NGAL and $\triangle \mathrm{NGAL}_{0-12 \mathrm{hr}}$ was independent predictors of unfavorable renal outcome. However, $\triangle \mathrm{NGAL}_{0-12 \mathrm{hr}}$ did not significantly correlated with the change of glomerular filtration rate between day 1 and day3.

${ }^{2}$ Chonbuk National University Hospital, Internal Medicine, Jeonju, Korea Republic of Korea

Full list of author information is available at the end of the article

\section{Conclusions}

Our data suggest that measurement of early serum NGAL change may be useful marker in predicting the renal impairment and need for renal replacement therapy in intensive care unit.

\section{Authors' details}

${ }^{1}$ Chonbuk National University Hospital, Nursing, Jeonju, Korea, Republic of Korea. ${ }^{2}$ Chonbuk National University Hospital, Internal Medicine, Jeonju, Korea, Republic of Korea.

Published: 1 October 2015

doi:10.1186/2197-425X-3-S1-A260

Cite this article as: Yu et al: Clinical usefulness of serial neutrophil geletinase-associated lipocalin (NGAL) change as a predictor for acute kidney injury. Intensive Care Medicine Experimental 2015 3(Suppl 1):A260.

Submit your manuscript to a SpringerOpen ${ }^{\bullet}$ journal and benefit from:

- Convenient online submission

- Rigorous peer review

- Immediate publication on acceptance

- Open access: articles freely available online

- High visibility within the field

- Retaining the copyright to your article

Submit your next manuscript at $\gg$ springeropen.com

\section{SpringerOpen ${ }^{\odot}$}

(c) 2015 Park et al.; This is an Open Access article distributed under the terms of the Creative Commons Attribution License (http:// creativecommons.org/licenses/by/4.0), which permits unrestricted use, distribution, and reproduction in any medium, provided the original work is properly cited. 